\title{
Inhibition of natural bacterial flora, Staphylococcus aureus, and enterotoxin A production in cooked ground chicken with oregano oil or tannic acid (TA) alone or combination
}

\author{
Marwan Al-Hijazeen ${ }^{1}$, Aubrey Mendonca ${ }^{2,3 *}$, Eun Joo Lee ${ }^{4}$, Dong Uk Ahn ${ }^{1 *}$ \\ ${ }^{1}$ Department of Animal Science, Iowa State University, Ames, IA 50011, USA \\ ${ }^{2}$ Department of Food Science and Human Nutrition, Iowa State University, Ames, IA 50011, USA \\ ${ }^{3}$ Interdepartmental Program in Microbiology, Iowa State University, Ames, IA 50011, USA \\ ${ }^{4}$ Department of Food and Nutrition, Wisconsin-Stout University, Menomonie, WI 54751, USA
}

\begin{abstract}
The effect of oregano oil and tannic acid (TA) on the aerobic plate count, Staphylococcus aureus growth, and staphylococcal enterotoxin A (SEA) production in cooked chicken breast meat held at abusive temperatures were evaluated. Five treatments, namely, control, $200 \mathrm{ppm}$ oregano essential oil, $10 \mathrm{ppm}$ TA, $200 \mathrm{ppm}$ oregano oil + $10 \mathrm{ppm}$ TA, and $5 \mathrm{ppm}$ butylated hydroxyanisole (BHA), were prepared. The antimicrobial effect of TA was weaker than that of the oregano oil or BHA, and TA did not decrease the $A P C$ at the end of the storage at $10^{\circ} \mathrm{C}$ or $25^{\circ} \mathrm{C}$. Oregano oil + TA treatment (combination) significantly suppressed the $\mathrm{APC}$ at all temperatures $\left(10^{\circ} \mathrm{C}, 25^{\circ} \mathrm{C}\right.$, and $43^{\circ} \mathrm{C}$ ) tested. Oregano oil $+\mathrm{TA}$ (combination) was the most effective treatment for inhibiting $S$. aureus growth at $10^{\circ} \mathrm{C}$ and $25^{\circ} \mathrm{C}$. All treatments inhibited SEA production in cooked chicken at $25^{\circ} \mathrm{C}$; however, oregano oil + TA (combination) was the most effective in inhibiting SEA production at $10^{\circ} \mathrm{C}$ and $43^{\circ} \mathrm{C}(7$ days and $6 \mathrm{~h}$, respectively). Based on these results, oregano oil has strong antimicrobial activity, which increases when combined with TA. Oregano oil + TA has a good potential for inhibiting the natural bacterial flora, growth of $S$. aureus, and SEA production in cooked chicken to enhance the microbial quality and safety under temperature abuse conditions.
\end{abstract}

Keywords : oregano essential oil, tannic acid, natural bacterial flora, Staphylococcus aureus, cooked chicken meat

\section{Introduction}

Several foods, including ground meats, are a vehicle for transmitting enteric pathogenic bacteria to humans. The World Health Organization (WHO) reported that foodborne diseases cause high levels of morbidity and mortality in the general population. This is especially true for immunecompromised persons, including infants and young children, the elderly, pregnant women, organ transplant patients, and patients undergoing chemotherapy (WHO, 2013; WHO,
2021). Meat is an important part of the human diet and an excellent medium for microbe growth, including human enteric pathogens. The contamination of meat by pathogens can occur before or after processing of meat products (Jay, 2000) and through cross-contamination from carcasses, handling, processing equipment, water, air, and food contact surfaces (Kadariya et al., 2014; Rodriguez et al., 2017; Rouger et al., 2017). However, the occurrence of foodborne illness depends on the ability of pathogens to survive or grow in raw or cooked meat. For example, Staphylococcus

\footnotetext{
*Corresponding author. Aubrey Mendonca. E-mail : amendon@iastate.edu, Phone : +1-515-294-2950

Dong Uk Ahn. E-mail : duahn@iastate.edu, Phone : +1-515-294-9078, Fax : +1-515-294-8181

Received 09 November 2021; Revised 13 December 2021; Accepted 16 December 2021.

Copyright (c) The Korean Society of Food Preservation.

This is an Open Access article distributed under the terms of the Creative Commons Attribution Non-Commercial License (http://creativecommons.org/licenses/by-nc/4.0) which permits unrestricted non-commercial use, distribution, and reproduction in any medium, provided the original work is properly cited.
} 
aureus, which competes poorly with other microbes in raw meat, grows better in cooked meat due to reduced microbial competition (Jay et al., 2005; Normanno et al., 2007).

Poultry meat is the most popular meat but is easily contaminated by microorganisms, including enteric pathogenic bacteria, during slaughtering and processing (Chouliara et al., 2007; Rouger et al., 2017). Reducing further microbial contamination and growth on poultry meat can be achieved by hygienic food handling and the use of safe storage temperatures, respectively (Solomakos et al., 2008; Todd, 2020; Vernozy-Rozand et al., 2002). Argudin et al. (2010) reported that $S$. aureus food poisoning mainly results from improper food handling and subsequent holding of food at elevated temperatures. Although $S$. aureus can be eliminated by thorough cooking, it can contaminate cooked meats from unhygienic practices of food handlers who carry this pathogen in their nostrils, skin, or gastrointestinal tract (Bencardino et al., 2021; Fooladvand et al., 2019). The growth of $S$. aureus in cooked meats can produce high heat-stable enterotoxins, which are not destroyed even if the meat is properly reheated or cooked again (Jay et al., 2005). This problem is further exacerbated when contaminated cooked meats are held at abusive temperatures that favor the rapid growth of $S$. aureus. Toxin production by $S$. aureus in ready-to-eat foods poses a major health risk to consumers and warrants testing of antimicrobial interventions to prevent the growth of that pathogen.

In recent years, the food industry has developed a greater interest in using natural antimicrobials instead of synthetic ones to satisfy consumer demand for more natural food preservatives (Pisoschi et al., 2017; Solomakos et al., 2008; Zhang et al., 2009). In this respect, several spices, herbs, and plant extracts have been evaluated for their antimicrobial activities (Chung et al., 1993; Erkmen and Ozcan, 2001; Horosova et al., 2006; Mostafa et al., 2018). Certain plant-based extracts such as oregano oil and TA exhibit antimicrobial activity because of their chemical composition (Botsoglou et al., 2003; Burt, 2004; Kaczmarek, 2020; Scalbert, 1991). For example, oregano oil contains a high level of phenolic compounds such as carvacrol and thymol, responsible for its major antimicrobial activity (Beuchat, 1994; Rostro-Alanis et al., 2019; Simirgiotis et al., 2020; Sivropoulou et al., 1996). The antimicrobial mechanisms of TA are linked to its astringent effect, enzyme and substrate complex formation, and metal chelating activity (Chung, 1993; Chung, 1998; Dong et al., 2018; Kaczmarek, 2020). Tannic acid has been well studied and proven for its inhibitory activity against several types of pathogens (Kaczmarek, 2020; Kim et al., 2010; Maisetta et al., 2019). While there is a growing body of knowledge on the antimicrobial effects of oregano oil or TA applied singly in foods, there are no published reports on the combined efficacy of these two natural antimicrobials for controlling microbial control or staphylococcal enterotoxin production in cooked ground chicken meat. Accordingly, the main objective of the present study was to evaluate the effect of oregano oil or TA alone or combined on the aerobic plate count and $S$. aureus growth and enterotoxin production in cooked ground chicken meat held under temperature abuse conditions.

\section{Materials and methods}

\section{Sample preparation}

The raw chicken breast meat was obtained from a local grocery store in Ames, IA, USA and ground twice through a $10-\mathrm{mm}$ plate and then a 3-mm plate (Kitchen Aid, Inc., St. Joseph, MI, USA). Five treatments were prepared: 1) control (no antimicrobial), 2) $200 \mathrm{ppm}$ oregano oil, 3) 10 ppm TA, 4) $200 \mathrm{ppm}$ oregano oil $+10 \mathrm{ppm} \mathrm{TA}$, and 5) 5 ppm butylated hydroxyanisole (BHA). The amounts of oregano oil and TA used were selected from preliminary studies (Al-Hijazeen et al., 2016; Al-Hijazeen et al., 2018) to achieve the maximum antioxidant benefits of the additives. The oregano oil was obtained from a certified company in Turkey (Healthy-Health, Staten Island, NY, USA). The GC/MS analysis of the oregano oil indicated that $80.12 \%$ of the oil was carvacrol. BHA powder $(0.1 \mathrm{~g})$ and oregano oil $(1.25 \mathrm{~g})$ were each dissolved in separate volumes $(10-\mathrm{mL})$ of $100 \%$ ethanol and then mixed with 50 $\mathrm{mL}$ mineral oil to make their stock solutions. The added ethanol was removed using a rotary evaporator (Model BUCH Rotavapor R-200, New Castle, DE, USA) at $70^{\circ} \mathrm{C}$, 175 mbar vacuum pressure before adding the stock solutions to the meat samples. Tannic acid powder (Sigma Chemical Co., St. Louis, MO, USA) was dissolved in sterile de-ionized water before adding it to the meat. Each treatment was added to the ground raw chicken meat and 
then mixed for $2 \mathrm{~min}$ in a bowl mixer (Model KSM 90; Kitchen Aid Inc., St. Joseph, MI, USA). All treatments were added with the same amounts of water and mineral oil to provide the same moisture and oil conditions. Control samples received the same water and mineral oil volume but without antimicrobial.

Samples of ground chicken meat (-100 g each) were individually packaged in separate oxygen-permeable bags (polyethylene, 4×6.2 mil, Associated Bag Co., Milwaukee, WI). The samples were then vacuum-packaged in oxygenimpermeable vacuum bags $\left(\mathrm{O}_{2}\right.$ permeability, $9.3 \mathrm{~mL} \mathrm{O} / \mathrm{m}^{2} /$ $24 \mathrm{~h}$ at $0^{\circ} \mathrm{C}$, Koch, Koch, Kansas City, MO, USA) and cooked in-bag in a $90^{\circ} \mathrm{C}$ water bath (Isotemp ${ }^{\circledR}$, Fisher Scientific Inc., Pittsburgh, PA, USA) until the internal temperature of the meat reached $75^{\circ} \mathrm{C}$. After cooling to room temperature, the cooked meat samples were individually re-packed in oxygen-permeable bags (polyethylene, $4 \times 6.2$ mil). All meat samples were stored in a walk-in cooler $\left(4.4^{\circ} \mathrm{C}\right)$ and used in experiments two $\mathrm{h}$ after preparation.

\section{Preparation of bacterial cultures}

Four strains of Staphylococcus aureus (ATCC 6538, ATCC 25923, ATCC 10390, ATCC 29213) known to produce staphylococcal enterotoxin A (SEA) were obtained from the Microbial Food Safety Laboratory at Iowa State University (Ames, IA, USA). Frozen stocks (in $10 \%$ glycerol at $-80^{\circ} \mathrm{C}$ ) were thawed and activated via two consecutive 24 -h transfers in $10 \mathrm{~mL}$ of tryptic soy broth (TSB; Becton Dickinson, Sparks MD, USA) to prepare the working cultures. Each working culture was grown in $10 \mathrm{~mL}$ of TSB supplemented with $0.6 \%$ yeast extract (TSBYE) at $35^{\circ} \mathrm{C}$ for $24 \mathrm{~h}$. Two consecutive 24-h transfers of each $S$. aureus strain were prepared in TSBYE $\left(35^{\circ} \mathrm{C}\right)$. Prior to each experiment, a portion $(6 \mathrm{~mL})$ of each of the cultures in TSBYE was aseptically transferred to a sterile centrifuge tube to obtain $24 \mathrm{~mL}$ of the 4-strain strain mixture of $S$. aureus.

The $S$. aureus cells in the 4-strain mixture were harvested by centrifugation $\left(10,000 \times g\right.$ for $\left.10 \mathrm{~min}, 4^{\circ} \mathrm{C}\right)$ using a Sorvall Super T21 centrifuge (American Laboratory Trading, Inc., East Lyme, CT, USA). The pelleted cells were re-suspended in $24 \mathrm{~mL}$ of sterile $0.85 \%(\mathrm{w} / \mathrm{v}) \mathrm{NaCl}$ (saline), washed by vortex-mixing, and then harvested by centrifugation as previously stated. The harvested cells were suspended in fresh saline and appropriately diluted in saline to obtain $-10^{7}$ colony forming units $(\mathrm{CFU}) / \mathrm{mL}$ for inoculating the cooked chicken.

\section{Inoculation of meat samples}

For inoculation and microbial analysis, samples of cooked chicken meat were transported to the Microbial Food Safety Laboratory (Dept. of Food Science \& Human Nutrition). Each sample was inoculated with $0.1 \mathrm{~mL}$ of $S$. aureus cell suspension to give an initial cell concentration of $-10^{4}$ colony forming units $(\mathrm{CFU}) / \mathrm{g}$. The inoculated packages of ground chicken were loosely closed, manually mixed for 30 s from outside of the bag, and held at $10^{\circ} \mathrm{C}, 25^{\circ} \mathrm{C}$, and $43^{\circ} \mathrm{C}$. Additionally, $0.1-\mathrm{mL}$ aliquots of sterile saline were added to bags of non-inoculated ground chicken, which were then loosely closed, manually mixed from outside of the bag, and held at those same temperatures. At set intervals during storage, the non-inoculated and inoculated chicken samples were analyzed for aerobic plate count (APC) and numbers of viable $S$. aureus, respectively. Samples of inoculated chicken were also taken for determining the presence of SEA.

\section{Microbial analysis}

Packages of cooked chicken were aseptically opened, and two-25 g portions of meat were aseptically transferred into separate sterile Seward ${ }^{\mathrm{TM}}$ Stomacher $^{\mathrm{TM}} 80$ Strainer bags (Thermo Fisher Scientific, Lenexa, KS). Sterile 0.1\% (w/v) peptone $(225 \mathrm{~mL})$ was added to each bag. The mixtures were homogenized in a laboratory blender (Stomacher 400, Seward, Worthington, UK), operating at medium speed. Serial dilutions (10-fold) of the meat homogenates were prepared in tubes of $0.1 \%(\mathrm{w} / \mathrm{v})$ peptone, and $0.1-\mathrm{mL}$ aliquots of diluted homogenate were surface plated on tryptic soy agar (TSA; for non-inoculated samples) and Baird-Parker agar (BPA; Becton Dickinson, Sparks, MD, USA) supplemented with egg yolk tellurite emulsion (for inoculated samples) to determine the APC and numbers of viable $S$. aureus, respectively. All inoculated agar plates were incubated at $35^{\circ} \mathrm{C}$, and bacterial colonies were counted after $48 \mathrm{~h}$.

\section{Assay for enterotoxin}

At set intervals during storage, a 10-g portion of cooked ground chicken from control and each treated sample was aseptically weighed in sterile aluminum foil and transferred to separate, sterile, appropriately labeled screw-cap centrifuge tubes. Fifteen $\mathrm{mL}$ of phosphate-buffered saline (PBS) were 
added to each 10-g sample, and the mixture was homogenized by vigorous vortex-mixing for 1.0 minutes, and the homogenates were subjected to centrifugation $(10,000 \times g, 5$ $\left.\min , 10^{\circ} \mathrm{C}\right)$. To determine enterotoxin's occurrence, each supernatant was filtered through a separate $0.22 \mu \mathrm{m}$ pore size low protein-binding MF-Millipore ${ }^{\mathrm{TM}}$ membrane filter (EMD Millipore, Billerica, MA, USA). Each filtrate was analyzed using the SET-RPLA Staphylococcal Enterotoxin Test Kit (Thermo Fisher Scientific, Lenexa, KS, USA) according to the manufacturer's instructions. Test results were expressed as positive (+) and (-) negative for enterotoxin production.

\section{Statistical analysis}

The experiment was a completely randomized design (CRD). Two separate samples per treatment per replication were analyzed over two replications of each experiment. The statistical analysis was performed using the SPSS (Chicago, IL, USA) package for Windows (Ver. 20.0). The mean values were compared using the one-way analysis of variance (ANOVA) followed by Duncan's multiple range tests $(p<0.05)$. Mean values and standard error of the means (SEM) were reported.

\section{Results and discussion}

Table 1 shows the APC of cooked chicken patties during storage at $10^{\circ} \mathrm{C}$ for 5 days. The initial APC of the cooked samples ranged from 1.79 to $2.58 \mathrm{log} \mathrm{CFU} / \mathrm{g}$. These APC results are consistent with an APC of about $2.0 \log \mathrm{CFU} / \mathrm{g}$ usually reported for freshly prepared cooked meat products (Tompkin et al., 2001). There was no significant difference in the initial APC (day 0) between control and TA-treated neat $(p>0.05)$; however, compared to control and TA, all other treatments resulted in significantly lower initial APC $(p<0.05)$. These results suggest that oregano oil alone or combined with TA and BHA reduced the numbers of bacterial survivors of the cooking process. Oregano oil has been reported to increase the heat destruction of bacteria (Dogruyol et al., 2020; Haberbeck et al., 2012; Xu et al., 2021). In the control chicken at $10^{\circ} \mathrm{C}$, the initial APC increased to 7.54- and $8.31 \log$ CFU/g after 3 and 5 days, respectively $(\mathrm{p}<0.05)$. Both control meat and meat treated with TA alone each had an APC (log CFU/g) of greater than 7.0 (after day 3) and 8.0 (after day 5). There was no significant difference between the APCs ( $p>0.05)$. In contrast, meat treated with oregano oil alone or combined with TA strongly suppressed bacterial growth; the APCs after 3 or 5 days were significantly lower than the APC in control meat and meat treated with TA or BHA alone $(\mathrm{p}<0.05)$. After 8 days, the APC $(\log \mathrm{CFU} / \mathrm{g})$ of chicken treated with oregano alone, oregano + TA or BHA was significantly $(p<0.05)$ lower than APC of control chicken and ranged from 6.25 (oregano oil $+\mathrm{TA}$ ) to 6.71 (BHA).

In the present study, the temperature of $10^{\circ} \mathrm{C}$ simulated temperature abuse conditions in a defective refrigerated

Table 1. Aerobic plate count of cooked chicken patties during storage at $10^{\circ} \mathrm{C}$ for 5 days

\begin{tabular}{|c|c|c|c|c|c|}
\hline \multirow{2}{*}{ Treatments } & \multicolumn{5}{|c|}{ Storage (days) } \\
\hline & 0 day & 1 day & 3 days & 5 days & SEM \\
\hline \multicolumn{6}{|c|}{ 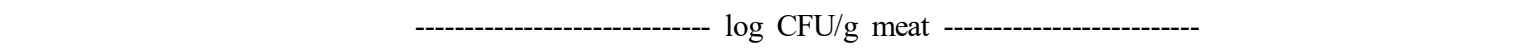 } \\
\hline Control & $2.6^{\mathrm{dw}}$ & $4.3^{\mathrm{cx}}$ & $7.5^{\mathrm{cy}}$ & $8.3^{\mathrm{cz}}$ & 0.04 \\
\hline Tannic acid & $2.5^{\mathrm{dw}}$ & $3.9^{\mathrm{abx}}$ & $7.3^{\mathrm{cy}}$ & $8.3^{\mathrm{cz}}$ & 0.08 \\
\hline Oregano & $2.0^{\mathrm{bw}}$ & $4.3^{\mathrm{cx}}$ & $5.7^{\mathrm{ay}}$ & $6.3^{\mathrm{az}}$ & 0.04 \\
\hline Combination & $1.8^{\mathrm{aw}}$ & $3.7^{\mathrm{ax}}$ & $5.7^{\text {ay }}$ & $6.3^{\mathrm{az}}$ & 0.03 \\
\hline BHA & $2.3^{\mathrm{cw}}$ & $4.1^{\mathrm{bcx}}$ & $5.9^{\text {by }}$ & $6.7^{\mathrm{bz}}$ & 0.03 \\
\hline SEM & 0.04 & 0.07 & 0.03 & 0.05 & \\
\hline
\end{tabular}

${ }^{a-e}$ Different superscripts within a column differ significantly $(\mathrm{p}<0.05)$.

${ }^{\mathrm{x}-\mathrm{z}}$ Different superscripts within a row differ significantly $(\mathrm{p}<0.05)$.

Treatments: Tannic acid, 10 ppm tannic acid; Oregano, 200 ppm oregano essential oil; Combination, 10 ppm tannic acid +200 ppm oregano essential combination. 
storage unit. It is expected that bacterial growth in cooked chicken will occur faster at $10^{\circ} \mathrm{C}$ than at proper refrigeration temperature of $4^{\circ} \mathrm{C}$ or less. In this respect, signs of microbial spoilage (off-odors) were readily detected in the control and TA-treated meat after 5 days of storage; however, no off-odors were detected in meats treated with oregano oil, oregano oil + TA, or with BHA. These results indicate the effectiveness of oregano oil alone or combined with TA and BHA for preventing bacterial spoilage of cooked chicken meat patties stored at $10^{\circ} \mathrm{C}$ for 5 days.

Table 2 shows the APC of cooked chicken patties during storage at $25^{\circ} \mathrm{C}$ and $43^{\circ} \mathrm{C}$ for $8 \mathrm{~h}$. At $25^{\circ} \mathrm{C}$ the initial APC of the control chicken increased to $6.88 \log \mathrm{CFU} / \mathrm{g}$ after 8 $\mathrm{h}$ representing a $4.28 \log \mathrm{CFU} / \mathrm{g}$ increase in the initial count. An almost similar increase was observed in TA-treated chicken meat, with an APC count of $6.68 \mathrm{log}$ CFU/g after $8 \mathrm{~h}$. In contrast, after $8 \mathrm{~h}$, all other treatments, except for TA, resulted in significantly lower APC than control $(\mathrm{p}<0.05)$. Of all the treatments tested, oregano oil $+\mathrm{TA}$ resulted in the lowest APC (5.26 log CFU/g) in the chicken meat after $8 \mathrm{~h}(\mathrm{p}<0.05)$.

A similar trend in the increase in the APC was observed for samples of cooked chicken meat held at $43^{\circ} \mathrm{C}$ (Table 2). One notable difference was that after $8 \mathrm{~h}$, the APC in control meat reached $8.32 \log \mathrm{CFU} / \mathrm{g}$, which was $1.44 \log$ $\mathrm{CFU} / \mathrm{g}$ higher than the APC for control meat at $25^{\circ} \mathrm{C}$. This result was not surprising considering that bacterial growth rate increases at higher temperatures within limits for growth. Moreover, bacterial survivors of the heat treatment $\left(75^{\circ} \mathrm{C}\right.$ internal temperature) applied to chicken meat were most likely bacterial spores and/or vegetative cells of thermoduric bacteria (Mendonca, 2010). While mesophilic thermoduric bacteria grow optimally at 30 to $37^{\circ} \mathrm{C}$, they can generally grow at temperatures up to $50^{\circ} \mathrm{C}$ (Henderson, 2018). At $43^{\circ} \mathrm{C}$, from 2 to $8 \mathrm{~h}$, all treated samples of cooked chicken had significantly $(\mathrm{p}<0.05)$ lower APC compared to control (Table 2). Among those treatments, the combination treatment (oregano oil + TA) was the most effective in

Table 2. Aerobic plate count of cooked chicken patties held at $20^{\circ} \mathrm{C}$ or $43^{\circ} \mathrm{C}$ for $8 \mathrm{~h}$

\begin{tabular}{|c|c|c|c|c|c|c|}
\hline \multirow{2}{*}{ Treatments } & \multicolumn{6}{|c|}{ Storage (hrs) } \\
\hline & $0 \mathrm{~h}$ & $2 \mathrm{~h}$ & $4 \mathrm{~h}$ & $6 \mathrm{~h}$ & $8 \mathrm{~h}$ & SEM \\
\hline & & $-\cdots$ & $\mathrm{CFU} / \mathrm{g}$ & - & & \\
\hline \multicolumn{7}{|l|}{ Storage at $25^{\circ} \mathrm{C}$} \\
\hline Control & $2.6^{\mathrm{cv}}$ & $3.5^{\mathrm{acw}}$ & $4.5^{\mathrm{dx}}$ & $5.5^{\mathrm{ey}}$ & $6.9^{\mathrm{cz}}$ & 0.04 \\
\hline Tannic acid & $2.5^{\mathrm{cv}}$ & $3.5^{\mathrm{cw}}$ & $4.3^{\mathrm{cx}}$ & $5.3^{\mathrm{dy}}$ & $6.7^{\mathrm{cz}}$ & 0.04 \\
\hline Oregano & $2.3^{\text {bv }}$ & $2.9^{\mathrm{bw}}$ & $3.6^{\mathrm{ax}}$ & $4.3^{\text {by }}$ & $5.7^{\mathrm{bz}}$ & 0.04 \\
\hline Combination & $2.2^{\mathrm{av}}$ & $2.6^{\mathrm{aw}}$ & $3.6^{\mathrm{ax}}$ & $4.1^{\text {ay }}$ & $5.3^{\mathrm{az}}$ & 0.05 \\
\hline BHA & $2.1^{\mathrm{av}}$ & $2.6^{\mathrm{aw}}$ & $3.8^{\mathrm{bx}}$ & $4.9^{\text {cy }}$ & $5.6^{\mathrm{bz}}$ & 0.09 \\
\hline SEM & 0.03 & 0.05 & 0.04 & 0.04 & 0.09 & \\
\hline \multicolumn{7}{|l|}{ Storage at $43^{\circ} \mathrm{C}$} \\
\hline Control & $2.6^{\mathrm{cv}}$ & $3.9^{\mathrm{dw}}$ & $5.1^{\mathrm{ex}}$ & $6.2^{\mathrm{dy}}$ & $8.3^{\mathrm{dz}}$ & 0.03 \\
\hline Tannic acid & $2.5^{\mathrm{cv}}$ & $3.7^{\mathrm{cw}}$ & $4.9^{\mathrm{dx}}$ & $5.8^{\mathrm{cy}}$ & $7.8^{\mathrm{cz}}$ & 0.03 \\
\hline Oregano & $2.3^{\text {bv }}$ & 2. $9^{\mathrm{bw}}$ & $3.7^{b x}$ & $4.7^{\text {by }}$ & $6.7^{\mathrm{bz}}$ & 0.03 \\
\hline Combination & $2.1^{\mathrm{av}}$ & $2.7^{\text {aw }}$ & $3.5^{\mathrm{ax}}$ & $4.3^{\mathrm{ay}}$ & $6.5^{\mathrm{az}}$ & 0.01 \\
\hline BHA & $2.1^{\mathrm{av}}$ & $2.9^{\mathrm{bw}}$ & $3.8^{\mathrm{cx}}$ & $4.7^{\text {by }}$ & $6.8^{\mathrm{bz}}$ & 0.03 \\
\hline SEM & 0.02 & 0.04 & 0.02 & 0.02 & 0.03 & \\
\hline
\end{tabular}

${ }^{\mathrm{a}-\mathrm{e}}$ Different superscripts within a column (for a specified storage temperature) differ significantly $(\mathrm{p}<0.05)$.

${ }^{x-z}$ Different superscripts within a row (for a specified storage temperature) differ significantly $(\mathrm{p}<0.05)$. $n=4$.

Treatments: Tannic acid, 10 ppm tannic acid; Oregano, 200 ppm oregano essential oil; Combination, 10 ppm tannic acid +200 ppm oregano essential combination. 
controlling the APC $(\mathrm{p}<0.05)$. Chicken with added oregano oil + TA had significantly lower APC than chicken with oregano oil alone $(\mathrm{p}<0.05)$. Although off-odors were readily detected on opening packages of control and TA-treated chicken after $8 \mathrm{~h}$, no off-odor was detected in chicken that contained oregano oil alone or oregano $+\mathrm{TA}$ and in samples with added BHA (data not shown). Based on these results, oregano oil alone or combined with TA is highly effective as a natural antimicrobial agent for suppressing the growth of indigenous bacteria in cooked chicken patties to retard bacterial spoilage of this meat product at $25^{\circ} \mathrm{C}$ or $43^{\circ} \mathrm{C}$ for $8 \mathrm{~h}$.

The numbers of viable $S$. aureus in artificially inoculated cooked ground chicken stored at $10^{\circ} \mathrm{C}$ for 7 days are shown in Table 3. After 7 days, the initial numbers of $S$. aureus in the control chicken increased from 4.32 to $8.39 \mathrm{log}$ $\mathrm{CFU} / \mathrm{g}$ representing a $4.07 \mathrm{log}$ increase. Compared to control, all treatments tested resulted in significantly $(p<0.05)$ lower numbers of the pathogen throughout storage of the cooked chicken. Of all the treatments tested, oregano + TA significantly decreased pathogen numbers after 3, 5, and 7 days $(\mathrm{p}<0.05)$.

Although $S$. aureus is mesophilic, some strains of this pathogen grow at temperatures as low as $6.7^{\circ} \mathrm{C}$. However, $S$. aureus can generally grow over a temperature range of $7^{\circ} \mathrm{C}$ to $47.8^{\circ} \mathrm{C}$ with optimum growth at $35^{\circ} \mathrm{C}$ (Bennett and Monday, 2003). Based on the present study results, S. aureus grew well in the cooked ground chicken meat at $10^{\circ} \mathrm{C}$ and reached high numbers $(>6.0 \log \mathrm{CFU} / \mathrm{g})$ after 3 days.
Moreover, meat samples with added oregano oil alone or combined with TA significantly $(\mathrm{p}<0.05)$ suppressed the growth of the pathogen (Table 3). These results suggest that incorporating oregano oil or oregano oil + TA in raw ground chicken can cause growth inhibition of $S$. aureus in the cooked product during storage at $10^{\circ} \mathrm{C}$.

Table 4 shows the numbers of viable $S$. aureus in cooked ground chicken patties held at $25^{\circ} \mathrm{C}$ or $43^{\circ} \mathrm{C}$ for $8 \mathrm{~h}$. Initial numbers of $S$. aureus increased rapidly and reached 6.32 and $8.72 \log \mathrm{CFU} / \mathrm{g}$ in control meat at $25^{\circ} \mathrm{C}$ and $43^{\circ} \mathrm{C}$, respectively, after $8 \mathrm{~h}$. At both temperatures, all treatments tested resulted in significantly lower pathogen numbers than control $(p<0.05)$. Among the treated samples $\left(25^{\circ} \mathrm{C}\right)$, those containing oregano oil + TA had significantly $(\mathrm{p}<0.05)$ lower numbers of $S$. aureus after $8 \mathrm{~h}$. After $6 \mathrm{~h}$ at the higher temperature $\left(43^{\circ} \mathrm{C}\right)$, numbers of viable $S$. aureus were significantly lower in chicken with oregano oil + TA compared to chicken with oregano oil alone $(\mathrm{p}<0.05)$. However, after $8 \mathrm{~h}$, there was no significant difference between the same treatments regarding the numbers of $S$. aureus $(\mathrm{p}>0.05)$.

The $25^{\circ} \mathrm{C}$ and $43^{\circ} \mathrm{C}$ were selected to simulate temperature abuse of cooked meat at ambient temperature $\left(25^{\circ} \mathrm{C}\right)$ and at an improper hot-holding temperature $\left(43^{\circ} \mathrm{C}\right)$ that may often occur in the home, restaurants or foodservice operations. The recommended minimum safe hot-holding temperature for ready-to-eat (RTE) foods, including cooked meats, is $140^{\circ} \mathrm{F}$ $\left(60^{\circ} \mathrm{C}\right)(\mathrm{FDA}, 2017)$. Potentially hazardous foods, including

Table 3. Numbers of viable Staphylococcus aureus in cooked ground chicken during storage at $10^{\circ} \mathrm{C}$ for 7 days

\begin{tabular}{|c|c|c|c|c|c|c|}
\hline \multirow{2}{*}{ Treatments } & \multicolumn{6}{|c|}{ Storage (days) } \\
\hline & 0 day & 1 day & 3 day & 5 day & 7 day & SEM \\
\hline & & -1-- & $\mathrm{CFU} / \mathrm{g}$ & - & & \\
\hline Control & $4.3^{\mathrm{av}}$ & $5.1^{\mathrm{dw}}$ & $6.8^{\mathrm{dx}}$ & $7.5^{\mathrm{dy}}$ & $8.4^{\mathrm{dz}}$ & 0.06 \\
\hline Tannic acid & $4.3^{\mathrm{av}}$ & $4.6^{\mathrm{bw}}$ & $5.5^{\mathrm{bx}}$ & $6.7^{\mathrm{cy}}$ & $7.3^{\mathrm{bz}}$ & 0.02 \\
\hline Oregano & $4.3^{\mathrm{aw}}$ & $4.3^{\mathrm{aw}}$ & $5.4^{\mathrm{bx}}$ & $6.5^{\text {by }}$ & $7.1^{\mathrm{bz}}$ & 0.07 \\
\hline Combination & $4.2^{\mathrm{aw}}$ & $4.3^{\mathrm{aw}}$ & $5.3^{\mathrm{ax}}$ & $6.0^{\mathrm{ay}}$ & $6.6^{\mathrm{az}}$ & 0.06 \\
\hline BHA & $4.2^{\mathrm{av}}$ & $4.9^{\mathrm{cw}}$ & $5.7^{\mathrm{cx}}$ & $6.7^{\mathrm{cy}}$ & $7.3^{\text {bz }}$ & 0.04 \\
\hline SEM & 0.07 & 0.02 & 0.02 & 0.05 & 0.08 & \\
\hline
\end{tabular}

${ }^{a-e}$ Different superscripts within a column of the same meat differ significantly $(p<0.05)$.

${ }^{\mathrm{x}-\mathrm{z}}$ Different superscripts within a row are differ significantly $(\mathrm{p}<0.05) . \mathrm{n}=4$.

Treatments: Tannic acid, 10 ppm tannic acid; Oregano, 200 ppm oregano essential oil; Combination, $10 \mathrm{ppm}$ tannic acid +200 ppm oregano essential combination. 
Table 4. Numbers of viable Staphylococcus aureus in cooked ground chicken held at $25^{\circ} \mathrm{C}$ or $43^{\circ} \mathrm{C}$ for $8 \mathrm{~h}$

\begin{tabular}{|c|c|c|c|c|c|c|}
\hline \multirow{2}{*}{ Treatments } & \multicolumn{6}{|c|}{ Storage (hrs) } \\
\hline & $0 \mathrm{~h}$ & $2 \mathrm{~h}$ & $4 \mathrm{~h}$ & $6 \mathrm{~h}$ & $8 \mathrm{~h}$ & SEM \\
\hline & & ------- & $\mathrm{CFU} / \mathrm{g}$ & (n- & & \\
\hline \multicolumn{7}{|l|}{ Storage at $25^{\circ} \mathrm{C}$} \\
\hline Control & $4.3^{\mathrm{av}}$ & $4.7^{\mathrm{cw}}$ & $5.4^{\mathrm{dx}}$ & $5.7^{\mathrm{dy}}$ & $6.3^{\mathrm{cz}}$ & 0.01 \\
\hline Tannic acid & $4.3^{\mathrm{av}}$ & $4.5^{\mathrm{abw}}$ & $4.8^{\mathrm{bcx}}$ & $5.2^{\mathrm{cy}}$ & $5.8^{\mathrm{bz}}$ & 0.03 \\
\hline Oregano & $4.3^{\mathrm{aw}}$ & $4.4^{\mathrm{abw}}$ & $4.8^{\mathrm{bx}}$ & $4.9^{\text {by }}$ & $5.8^{\mathrm{bz}}$ & 0.04 \\
\hline Combination & $4.2^{\mathrm{aw}}$ & $4.4^{\mathrm{ax}}$ & $4.6^{\mathrm{ax}}$ & $4.8^{\mathrm{ay}}$ & $5.3^{\mathrm{az}}$ & 0.07 \\
\hline BHA & $4.3^{\mathrm{aw}}$ & $4.5^{\mathrm{bx}}$ & $4.9^{\mathrm{cy}}$ & $4.9^{\text {by }}$ & $5.8^{\mathrm{bz}}$ & 0.02 \\
\hline SEM & 0.07 & 0.01 & 0.03 & 0.01 & 0.04 & \\
\hline \multicolumn{7}{|l|}{ Storage at $43^{\circ} \mathrm{C}$} \\
\hline Control & $4.3^{\mathrm{av}}$ & $5.3^{\mathrm{bw}}$ & $6.5^{\mathrm{dx}}$ & $7.7^{\mathrm{cy}}$ & $8.7^{\mathrm{dz}}$ & 0.01 \\
\hline Tannic acid & $4.3^{\mathrm{av}}$ & $4.7^{\mathrm{aw}}$ & $5.6^{\mathrm{bx}}$ & $6.8^{\text {by }}$ & $7.5^{\mathrm{bz}}$ & 0.02 \\
\hline Oregano & $4.3^{\mathrm{av}}$ & $4.6^{\mathrm{aw}}$ & $5.6^{\mathrm{bx}}$ & $6.8^{\text {by }}$ & $7.4^{\mathrm{abz}}$ & 0.05 \\
\hline Combination & $4.2^{\mathrm{av}}$ & $4.6^{\mathrm{aw}}$ & $5.4^{\mathrm{ax}}$ & $6.5^{\text {ay }}$ & $7.3^{\mathrm{az}}$ & 0.07 \\
\hline BHA & $4.3^{\mathrm{av}}$ & $4.7^{\text {aw }}$ & $5.8^{\mathrm{cx}}$ & $6.8^{\text {by }}$ & $7.6^{\mathrm{cz}}$ & 0.02 \\
\hline SEM & 0.06 & 0.02 & 0.04 & 0.02 & 0.03 & \\
\hline
\end{tabular}

${ }^{\mathrm{a}-\mathrm{e}}$ Different superscripts within a column (for a specified storage time) are differ significantly $(\mathrm{p}<0.05)$.

${ }^{\mathrm{x}-\mathrm{z}}$ Different superscripts within a row are differ significantly $(\mathrm{p}<0.05) . \mathrm{n}=4$.

Treatments: Tannic acid, 10 ppm tannic acid; Oregano, 200 ppm oregano essential oil; Combination, 10 ppm tannic acid +200 ppm oregano essential combination.

cooked meats, should not remain in the temperature danger zone [between $40^{\circ} \mathrm{F}\left(4.4^{\circ} \mathrm{C}\right)$ and $140^{\circ} \mathrm{F}\left(60^{\circ} \mathrm{C}\right)$ ] for more than $2 \mathrm{~h}$. That time is reduced to 1 hour if the temperature exceeds $90^{\circ} \mathrm{F}\left(32.2^{\circ} \mathrm{C}\right)$ (USDA, 2021). Such food safety actions are important because foodborne pathogenic bacteria can multiply rapidly within that area of the temperature danger zone. Our findings justify this recommended brief (1-hour) exposure because $S$. aureus multiplied faster and attained significantly $(\mathrm{p}<0.05)$ higher populations in the control meat after $2 \mathrm{~h}$ at $43^{\circ} \mathrm{C}$ compared to $25^{\circ} \mathrm{C}$ (Table 4). Consistently significant $(p<0.05)$ growth suppression of the pathogen in cooked chicken meat with a combination of oregano oil and TA was observed. This finding attests to the potential of that combination for controlling $S$. aureus growth in cooked chicken under conditions of temperature abuse. Several studies have reported the antimicrobial activity of oregano oil (Bahmani et al., 2019; Cui et al., 2019; Lu et al., 2018; Rodrigues et al., 2019) or TA (Akiyama et al., 2001; Dong et al., 2018; Kaczmarek, 2020; Ozcan, 2001) against $S$. aureus planktonic cells or as cells in biofilms. However, the present study is the first to report the antimicrobial activity of oregano oil and TA in combination against $S$. aureus in artificially inoculated cooked ground chicken meat under temperature abuse conditions.

Table 5 shows the effect of antimicrobial treatments on staphylococcal enterotoxin A (SEA) production in artificially inoculated cooked ground chicken held at $10^{\circ} \mathrm{C}, 25^{\circ} \mathrm{C}$, and $43^{\circ} \mathrm{C}$. In control meat at $10^{\circ} \mathrm{C}$, SEA was detected after 3 days, whereas al treatments inhibited SEA production at that time. After 5 days of storage, chicken samples that contained TA, oregano oil, or BHA tested positive for SEA. In contrast, SEA was not detected for 7 days in chicken that contained oregano oil + TA (Table 5). For cooked chicken at $25^{\circ} \mathrm{C}$, only control samples tested positive for SEA after $8 \mathrm{~h}$, whereas toxin was undetected in all the treated samples. At $43^{\circ} \mathrm{C}$, the cooked chicken exhibited SEA much earlier 
Table 5. Effect of antimicrobial treatments on production of staphylococcal enterotoxin $A$ in cooked ground chicken breast meat held at $10^{\circ} \mathrm{C}, 25^{\circ} \mathrm{C}$, and $43^{\circ} \mathrm{C}$

\begin{tabular}{|c|c|c|c|c|}
\hline \multirow{2}{*}{$10^{\circ} \mathrm{C}$ treatments } & \multicolumn{4}{|c|}{ Time (days) } \\
\hline & Day 1 & Day 3 & Day 5 & Day 7 \\
\hline Control & $-^{\mathrm{a}}$ & $++^{\mathrm{b}}$ & + & + \\
\hline Tannic acid & - & - & + & + \\
\hline Oregano & - & - & + & + \\
\hline Combination & - & - & - & - \\
\hline BHA & - & - & + & + \\
\hline \multirow{2}{*}{$25^{\circ} \mathrm{C}$ treatments } & \multicolumn{4}{|c|}{ Time (h) } \\
\hline & $2 \mathrm{~h}$ & $4 \mathrm{~h}$ & $6 \mathrm{~h}$ & $8 \mathrm{~h}$ \\
\hline Control & - & - & - & + \\
\hline Tannic acid & - & - & - & - \\
\hline Oregano & - & - & - & - \\
\hline Combination & - & - & - & - \\
\hline BHA & - & - & - & - \\
\hline $43^{\circ} \mathrm{C}$ treatments & $2 \mathrm{~h}$ & $4 \mathrm{~h}$ & $6 \mathrm{~h}$ & $8 \mathrm{~h}$ \\
\hline Control & - & + & + & + \\
\hline Tannic acid & - & - & + & + \\
\hline Oregano & - & - & + & + \\
\hline Combination & - & - & - & + \\
\hline BHA & - & - & + & + \\
\hline
\end{tabular}

${ }_{-}^{\mathrm{a}}$, negative test (no enterotoxin detected); $+^{\mathrm{b}}$, positive test (enterotoxin detected).

Treatments: Tannic acid, 10 ppm tannic acid; Oregano, 200 ppm oregano essential oil; Combination, 200 ppm oregano essential oil +10 ppm tannic acid.

than samples at $25^{\circ} \mathrm{C}$. For example, control samples $\left(43^{\circ} \mathrm{C}\right)$ were positive for SEA after $4 \mathrm{~h}$, and tannic acid-, oregano oil-, and BHA-treated samples were positive after $6 \mathrm{~h}$. Only chicken containing oregano oil + TA had SEA after $8 \mathrm{~h}$.

To test the SEA in the cooked chicken, the samples were held at $10^{\circ} \mathrm{C}, 25^{\circ} \mathrm{C}$, and $43^{\circ} \mathrm{C}$ because those abusive temperatures pose the greatest risk to food safety regarding toxin production by $S$. aureus. The $S$. aureus enterotoxins are produced within a broad temperature range of $10^{\circ} \mathrm{C}$ to $50^{\circ} \mathrm{C}$ (Schmidt et al., 1990). Unexpected temperature abuses can occur in the cold chain of refrigerated transport, storage, and distribution of ready-to-eat (RTE) foods, including cooked meats (Ndraha et al., 2018). In this respect, it is conceivable that frequent traffic in and out of refrigerated storage facilities or a defective cold storage unit can increase refrigerated temperatures to $10^{\circ} \mathrm{C}$ or higher. At $10^{\circ} \mathrm{C}$, SEA was produced in control cooked chicken as early as 3 days, whereas, in chicken with added oregano oil + TA, no SEA was detected through 7 days (Table 5). These results suggest that oregano oil $+\mathrm{TA}$ in cooked chicken at $10^{\circ} \mathrm{C}$ is effective in improving the microbial safety of that RTE food product by preventing toxin production by $S$. aureus.

While $S$. aureus can produce SEA at $10^{\circ} \mathrm{C}$, the toxin is produced faster and in larger amounts at higher temperatures (Tsutsuura et al., 2013). Although, the amounts of toxin in the cooked chicken were not quantified, our results support the findings of Tsutsuura et al. (2013) who detected SEA within $\mathrm{h}$ of holding the cooked chicken at $25^{\circ} \mathrm{C}$ or $43^{\circ} \mathrm{C}$ compared to days for chicken held at $10^{\circ} \mathrm{C}$. Moreover, SEA was produced faster in chicken at $43^{\circ} \mathrm{C}$ than at $25^{\circ} \mathrm{C}$ (Table 
5). At that higher temperature $\left(43^{\circ} \mathrm{C}\right)$, the combination of oregano oil + TA was the most effective treatment for inhibiting toxin production; no SEA was detected in the treated chicken for up to $6 \mathrm{~h}$ (Table 5).

The antibacterial effect of oregano oil is attributed to the relatively high level of carvacrol, thymol, and other polyphenolic components of that plant essential oil (Cui et al., 2019; Kachur and Suntres, 2020). Tannic acid has high binding efficiency for iron, making it like a siderophore to sequester iron from the environment and drastically limiting iron availability to bacteria. Many bacteria need iron for several biological functions, such as making heme compounds for the respiratory chain, reducing ribonucleotide precursors of DNA, serving as a co-factor for ironcontaining enzymes, and many essential processes for survival (Kaczmarek, 2020; Nelson et al., 2019). In the present study, the combined use of oregano oil and TA in cooked chicken likely exerted multiple stresses on the native bacterial flora and $S$. aureus in the cooked chicken. Those stresses, in turn, resulted in microbial growth inhibition and inhibition of SEA production.

\section{Conclusions}

Incorporating 200 ppm oregano oil +10 ppm TA in raw ground chicken is highly effective for inhibiting the natural bacterial flora, S. aureus growth, and toxin production in the cooked product. The combined application of those two natural antimicrobials has good potential for improving the microbial quality and safety of cooked chicken under temperature abuse conditions.

\section{Acknowledgment}

This work was supported by the Iowa Agriculture and Home Economics Experiment Station Project No. IOW04202 sponsored by Hatch Act and State of Iowa funds.

\section{Conflict of interests}

The authors declare no potential conflict of interest.

\section{ORCID}

Marwan Al-Hijazeen https://orcid.org/0000-0002-7717-7977
Aubrey Mendonca https://orcid.org/0000-0001-7258-4031

Dong Uk Ahn https://orcid.org/0000-0001-9523-7630

\section{References}

Akiyama H, Fujii K, Yamasaki O, Oono T, Iwastsuki K. Antibacterial action of several tannins against Staphylococcus aureus. J Antimicrob Chemother, 48, 487-491 (2001)

Al-Hijazeen M, Lee EJ, Mendonca A, Ahn DU. Effect of oregano essential oil (Origanum vulgare subsp. hirtum) on the storage stability and quality parameters of ground chicken breast meat. Antioxidants, 5, 1-11 (2016)

Al-Hijazeen M, Lee EJ, Mendonca A, Ahn DU. Effect of oregano oil and tannic acid combinations on the quality and sensory characteristics of cooked chicken meat. Poult Sci, 97, 676-683 (2018)

Argudín MA, Mendoza MC, Rodicio MR. Food poisoning and Staphylococcus aureus enterotoxins. Toxins, 2, 17511773 (2010)

Bahmani M., Taherikalani M, Khaksarian M, RafieianKopaei M, Ashrafi B, Nazer M. Soroush S, Abbasi N, Rashidipour M. The synergistic effect of hydroalcoholic extracts of Origanum vulgare, Hypericum perforatum and their active components carvacrol and hypericin against Staphylococcus aureus. Future Sci, 5, FSO371 (2019)

Bencardino D, Amagliani G, Brandi G. Carriage of Staphylococcus aureus among food handlers: An ongoing challenge in public health. Food Control, 130, 108362 (2021)

Bennett RW, Monday SR. Staphylococcus aureus. In International Handbook of Foodborne Pathogens, Miliotis DM, Bier WJ (Editors), Taylor \& Francis, Abingdon, UK, p 41-59 (2003)

Beuchat LR. Antimicrobial prosperities of spices and their essential oil. In: Natural Antimicrobial Systems and Food Preservation, Dillon VM, Board RG (Editors), CAB Int, Wallingford, Oxfordshire, UK, p 167-179 (1994)

Botsoglou NA, Grigoropopulou SH, Botsoglou E, Govaris A, Papageorgiou G. Antioxidant activity of dietary oregano essential oil and $\alpha$-tocopherol acetate supplementation in long-term frozen stored turkey meat. J Agric Food Chem, 51, 2930-2936 (2003)

Burt S. Essential oils: Their antibacterial properties and 
potential applications in foods - A review. Int J Food Microbiol, 94, 223-253 (2004)

Chouliara E, Karatapanis A, Savvaidis IN, Kontominas M. Combined effect of oregano essential oil and modified atmosphere packaging on the shelf-life extension of fresh chicken breast meat, stored at $4^{\circ} \mathrm{C}$. Food Microbiol, 24, 607-917 (2007)

Chung KT, Stevens SE, Lin WF, Wei CI. Growth inhibition of selected foodborne bacteria by tannic acid, propyl gallate, and related compounds. Lett Appl Microbiol, 17, 29-32 (1993)

Chung KT, Lu Z, Chou MW. Mechanism of inhibition of tannic acid and related compounds on the growth of intestinal bacteria. Food Chem Toxicol, 36, 1053-1560 (1998)

Cui HY, Zhang CH, Li CZ, Lin L. Antibacterial mechanism of oregano essential oil. Ind Crops Prod, 139, 111498 (2019)

Dogruyol H, Mol S, Cosansu S. Increased thermal sensitivity of Listeria monocytogenes in sous-vide salmon by oregano essential oil and citric acid. Food Microbiol, 90, 103496 (2020)

Dong G, Liu H, Yu X, Zhang X, Lu H, Zhou T, Cao J. Antimicrobial and anti-biofilm activity of tannic acid against Staphylococcus aureus. Natural Product Res, 32, 18, 2225-2228 (2018)

Erkmen O, Ozcan M. Antimicrobial activities of essential oils from Turkish spices. Eur Food Res Technol, 212, 658-660 (2001)

Fooladvand S, Sarmadian H, Habibi D, van Belkum A, Ghaznavi-Rad E. High prevalence of methicillin-resistant and enterotoxin gene-positive Staphylococcus aureus among nasally colonized food handlers in central Iran. Eur J Clin Microbiol Infect Dis, 38, 87-92 (2019)

Haberbeck LU, da Silva Riehl CB, Salomao B, de Aragao GMF. Bacillus coagulans spore inactivation through the application of oregano essential oil and heat. LWT Food Sci Technol, 46, 267-273 (2012)

Henderson A. A review of thermoduric bacteria: Significance, sources and management part 1. Livestock, 23 (2018)

Horosova K, Bujanova D, Kmet V. Effect of oregano oil on chicken lactobacilli and E. coli. Folia Microbiol, 51, 278-280 (2006)

Jay JM. Chap. 4. Microorganisms in foods: Fresh meat and poultry. In: Modern Food Microbiology, 6th ed. An Aspen Publisher, Inc., Gaithersburg, MD, USA, p 59-81 (2000)

Jay JA, Loessner MJ, Golden DA. Chap. 23. Staphylococcal gastroenteritis. In: Modern Food Microbiology, 7th ed. Springer Science, New York, NY, USA, p 545-562 (2005)

Kachur K, Suntres Z. The antibacterial properties of phenolic isomers, carvacrol and thymol. Crit Rev Food Sci Nutr, 60, 18, 3042-3053 (2020)

Kaczmarek B. Tannic acid with antiviral and antibacterial activity as a promising component of biomaterials - A mini-review. Materials, 13, 3224 (2020)

Kadariya J, Smith TC, Thapaliya D. Staphylococcus aureus and staphylococcal foodborne disease: An ongoing challenge in public health. Biomed Res Int, 2014, 827965 (2014)

Kim TJ, Silva JL, Kim MK, Jung YS. Enhanced antioxidant capacity and antimicrobial activity of tannic acid by thermal processing. Food Chem, 118, 740-746 (2010)

Lu M, Dai T, Murray CK, Wu MX. Bactericidal property of oregano oil against multidrug-resistant clinical isolates. Front Microbiol, 9, 2329 (2018)

Marietta G, Batoni G, Caboni P, Esin S, Rinaldi AC, Zucca P. Tannin profile, antioxidant properties, and antimicrobial activity of extracts from two Mediterranean species of parasitic plant Cytinus. BMC Compl Alt Med, 19, 82 (2019)

Mendonca AF. Microbiology of cooked meats. In: Thermal Processing of Ready-to-eat Meat Products, Knipe CL, Rust RE (Editors), Wiley-Blackwell, Ames, IA, USA, p 17-38 (2010)

Mostafa AA, Al-Askar AA, Almaary KS, Dawoud TM, Sholkamy EN, Bakri MM. Antimicrobial activity of some plant extracts against bacterial strains causing food poisoning diseases. Saudi J Biol Sci, 25, 361-366 (2018)

Nelson CE, Huang W, Brewer LK, Nguyen AT, Kane MA, Wilks A, Oglesby-Sherrouse AG. Proteomic analysis of the Pseudomonas aeruginosa iron starvation response reveals PrrF small regulatory RNA- dependent iron regulation of twitching motility, amino acid metabolism, and zinc homeostasis proteins. J Bacteriol, 201, e0075418 (2019)

Ndraha N, Hsiao HI, Vlajic J, Yang MF, Lin HTV. 
Time-temperature abuse in the food cold chain: Review of issues, challenges, and recommendations. Food Control, 89, 12-21 (2018)

Normanno G, LaSalandra G, Dambrosio A. Occurrence, characterization, and antimicrobial resistance of enterotoxigenic Staphylococcus aureus isolated from meat and dairy products. Int $\mathrm{J}$ Food Microbiol, 115, 290-296 (2007)

Ozcan M, Erkmen O. Antimicrobial activity of the essential oil of Turkish plant spices. Eur Food Res Technol, 212, 658-660 (2001)

Pisoschi A, Pop A, Cecilia G, Turcuş V, Olah NK, Mathe E. An overview of natural antimicrobials' role in food. Eur J Med Chem, 143, 922-935 (2018)

Rodrigues JBS, Carvalho RJ, Souza NT, Oliveira KS, Franco OL, Schaffner D, de Souza EL, Magnani M. Effects of oregano essential oil and carvacrol on biofilms of Staphylococcus aureus from food-contact surfaces. Food Control, 73, 1237-1246 (2017)

Roger A, Tresse O, Zagorec M. Bacterial contaminants of poultry meat: Sources, species, and dynamics. Microorganisms, 5, 50 (2017)

Rostro-Alanis MJ, Baez-González J, Torres-Alvarez C, Parra-Saldívar R, Rodriguez-Rodriguez J, Castillo S. Chemical composition and biological activities of oregano essential oil and its fractions obtained by vacuum distillation. Molecules, 24, 1904 (2019)

Scalbert A. Antimicrobial properties of tannins. Phytochem, 30, 3875-3883 (1991)

Schmidt M, Schuler-Schmidt U, Schmidt-Lorenz W. Temperature limits of growth, TNase and enterotoxin production of Staphylococcus aureus strains isolated from foods. Int J Food Microbiol, 11, 1-19 (1990)

Sivropoulou A, Papanikolaou E, Nikolaou C, Kokkini S, Landaras T, Arsenakis M. Antimicrobial and cytotoxic activities of Origanum essential oils. J Agric Food Chem, 44, 1202-1205 (1996)

Simirgiotis MJ, Burton D, Parra F, Lopez J, Munoz P, Escobar H, Parra C. Antioxidant and antibacterial capacities of Origanum vulgare L. essential oil from the arid Andean region of Chile and its chemical characterization by GC-MS. Metabolites, 10, 414 (2020)
Solomakos N, Govaris A, Koidis P, Botsoglou N. The antimicrobial effect of thyme essential oil, nisin, and their combination against Listeria monocytogenes in minced beef during refrigerated storage. Food Microbiol, 25, 120-127 (2008)

Todd E. Food-borne disease prevention and risk assessment. Int J Environ Res Public Health, 17, 5129 (2020)

Tompkin RB, McNamara AM, Acuff GR. Meat and poultry products. In: Compendium of Methods for the Microbiological Examination of Foods. Downs FP, Ito K (Editors), American Public Health Association, Washington, DC, p 463-471 (2001)

Tsutsuura S, Shimamura Y, Murata M. Temperature dependence of the production of staphylococcal enterotoxin A by Staphylococcus aureus. Biosci Biotechnol Biochem, 77, 30-37 (2013)

USDA Food Safety and Inspection Service. Temperature Danger Zone $\left(40{ }^{\circ} \mathrm{F}-140^{\circ} \mathrm{F}\right)$. https://www.fsis.usda.gov/ food-safety/safe-food-handling-and-preparation/food-safetybasics/danger-zone-40f-140f (2021) (accessed on October 16 2021)

Vernozy-Rozand C, Ray-Gueniot S, Ragot C, Bavai C, Mazuy C, Montet MP, Bouvet J, Richard Y. Prevalence of Escherichia coli $\mathrm{O} 157: \mathrm{H} 7$ in industrial minced beef. Lett Appl Microbiol, 35, 7-11 (2002)

World Health Organization (WHO). Food Safety and Foodborne Illness. Geneva, Switzerland, WHO. http://www.who.int/ foodsafety/foodborne_disease/en/. (2013) (accessed on May 26 2021)

World Health Organization (WHO). Estimating the Burden of Foodborne Diseases, Geneva, Switzerland, WHO. https:// www.who.int/activities/estimating-the-burden-of-foodbor ne-diseases. (2021) (accessed on Jun 2 2021)

Xu YM, Guan XY, Lin BY, Li R, Wang SJ. Oregano oil, epsilon-polylysine and citric acid assisted inactivation of Salmonella in two kinds of tahini during thermal treatment and storage. Foods, 10, 1272 (2021)

Zhang H, Kong B, Xiong YL, Sun X. Antimicrobial activities of spice extracts against pathogenic and spoilage bacteria in modified atmosphere packaged fresh pork and vacuum packaged ham slices stored at $4^{\circ} \mathrm{C}$. Meat Sci, 81, 686-692 (2009) 